\title{
PERAN ORANG TUA DALAM PENDIDIKAN ISLAM PADA ANAK
}

\author{
Abd. Syahid ${ }^{1)}$ Kamaruddin $^{2)}$ \\ 1)Dosen Tetap Program Studi Pendidikan Agama Islam STAI Auliaurrasyidin Tembilahan \\ Kabupaten Indragiri Hilir Propinsi Riau. Email: abd.syahid@ stai-tbh.ac.id \\ ${ }^{2)}$ Dosen Tetap Program Studi Pendidikan Agama Islam STAI Auliaurrasyidin Tembilahan \\ Kabupaten Indragiri Hilir Propinsi Riau. Email: kamaruddin@ stai-tbh.ac.id
}

\begin{abstract}
Abstrak
Kedua orang tua adalah pendidik bagi anak-anaknya karena secara kodrati, diberikan anugerah oleh Allah SWT berupa perasaan kasih sayang kepada anakanak mereka, hingga keduanya merasa punya rasa tanggung jawab untuk memelihara, mengawasi, melindungi, dan membimbing keturunan mereka. Keluarga merupakan lapangan pendidikan yang pertama kehidupan anak-anak dalam pembinaan karakter anak dan sebagai pendidiknya adalah kedua orang tua. Dalam pendidikan Islam kedua orang tua menjadi suatu kewajiban yang tidak bisa diabaikan dan ada beberapa hal yang harus diperhatikan dalam pendidikan agar menjadi generasi Islami selalu berdasarkan petunjuk Al-Qur'an dan Hadis Nabi SAW. Disamping itu perlu diperhatikan adalah kebutuhan psikologis dan biologis khususnya dalam bermain dengan teman-temannya, dengan berteman terbentuk solidaritas, pengetahuan tentang lingkungan bertambah dan hal lain yang positif. Dan juga perlu diperhatikan faktor yang sering mengganggu perkembangan anak seeperti tidak dimanfaatkannya waktu luang secara tepat, gemar bermain tanpa batas waktu, senang bersantai terutama pada saat belajar. Rumusan masalah yaitu; bagaimana pendidikan pada anak sesuai menurut Al-qur'an dan Al-Sunnah, apa saja tanggung jawab pokok orang tua terhadap anaknya, serta apa faktor yang mempengaruhi generasi Islami.
\end{abstract}

Kata Kunci: Peran Orang Tua, Pendidikan Islam

\section{PENDAHULUAN}

Pendidikan Islam merupakan proses menyampaikan pengetahuan dan nilai Islam kepada peserta didik melalui upaya pengajaran, pembiasaan, bimbingan, pengasuhan, pengawasan, dan pengembangan potensinya guna mencapai keselarasan dan kesempurnaan hidup di dunia maupun di akhirat. ${ }^{1}$

${ }^{1}$ Abdul Mujib, Jusuf Mudzakir, Ilmu Pendidikan Islam, (Jakarta: Kencana Prenada Media Group, 2008), h. 27-28 
Oleh sebab itu, Pendidikan Islam memberikan bimbingan dan petunjuk kepada semua petunjuk dan kepada semua penanggung jawab serta penyelenggara pendidikan baik di dalam keluarga, seklah dan di masyarakat. Lingkungan atau lembaga dalam arti luas adalah faktor-faktor yang secara langsung mempengaruhi kehidupan manusia, yang secara langsung pula dapat mempengaruhi perilaku. Proses perkembangan manusia setiap saat membutuhkan belajar dari lingkungan atau alam semesta sampai anak dapat menemukan cara bertindak untuk mempertahankan kehidupannya. ${ }^{2}$

Adapun lingkungan atau lembaga pendidikan yang berperan di dalam pendidikan anak: Pertama keluarga, merupakan wadah pertama dan utama bagi pertumbuhan dan pengembangan anak. Peranan ibu dalam keluarga sangat penting. Ibu yang mengatur, membuat rumah tangganya menjadi surga bagi anggota keluarga, manjadi mitra sejajar yang saling menyayangi dengan suaminya. ${ }^{3}$ Jadi, keluarga merupakan lingkungan yang sangat berpengaruh terhadap pendidikan anak. Apapun yang anak lihat, maupun dirasakan di lingkungan keluarga maka akan berpengaruh terhadap kpribadian anak. Maka selaku orangtua harus hati-hati dalam berbicara dan bersikap, karena hal itu akan memberikan dampak terhadap perkembangan pendidikan anak. Kedua Sekolah, merupakan tempat pendidikan kedua setelah keluarga, di dalamnya akan anak dapatkan berbagai macam ilmu pengetahuan. Pendidik, teman dan materi yang dijumpai di sekolah adalah unsur-unsur yang mempengaruhi pembentukan pribadi anak selain keluarga. ${ }^{4}$ Semua itu perlu didukung dengan guru-guru melaksanakan tugas pembinaan, pendidikan dan pengajaran tersebut adalah orangorang yang telah dibekali dengan pengetahuan tentang anak didik, dan memiliki kemampuan untuk melaksanakan tugas pendidikan. Ketiga Masyarakat, lembaga masyarakat besar pengaruhnya dalam memberi arah terhadap pendidikan anak, terutama para pemimpin masyarakat atau pengusaha yang ada di dalamnya. ${ }^{5}$ Oleh sebab itu masyarakat juga merupakan salah satu pendidik yang membentuk

\footnotetext{
${ }^{2}$ Mansur, Mendidik Anak Sejak Dalam Kandungan, (Yogyakarta: Mitra Pustaka, 2004), h. 113

3 Zakiah Daradjat, Pendidikan Islam Dalam Keluarga dan Sekolah, (Jakarta: Ruhama, 1995), h. 47.

4 Muhammad Hatta, Pendidikan Dalam Perspektif Al-Ghazali, (Jambi: Sulthan Thaha Press IAIN STS Jambi,2010), h.91

${ }^{5}$ Zakiah Daradjat, Ilmu Pendidikan Islam, (Jakarta: Bumi Aksara, 2012), h. 45
} 
kepribadian seorang anak, jika seorang anak berada maupun bergaul pada masyarakat yang baik, maka anak akan memiliki prilaku yang baik, begitu juga sebaliknya.

\section{METODE PENELITIAN}

Jenis penelitian menggunakan pendekatan deskriptif kualitatif yang penulis gunakan adalah library research yaitu mengumpulkan buku-buku yang berkaitan dengan objek penelitian atau penelitian yang bersifat kepustakaan.

1. Sumber Data

Kajian yang penulis gunakan adalah penelitian perpustakaan murni, penulis akan menggunakan dua sumber, yaitu:

a. Sumber Primer

Sumber data yang berifat primer adalah buku rujukan awal dan utama dalam penelitian, sumber primer yang penulis gunakan adalah:

i. Abdul Mujib, Jusuf Mudzakir, Ilmu Pendidikan Islam, (Jakarta: Kencana Prenada Media Group, 2008)

ii. Ahmad Tafsir, Ilmu Pendidikan Islami, (Bandug: PT Remaja Rosdakarya, 2012)

iii. Marzuki, Pendidikan Karakter Islam, (Jakarta: Amzah, 2015)

iv. Mansur, Mendidik Anak Sejak Dalam Kandungan, (Yogyakarta: Mitra Pustaka, 2004)

v. Muhammad Hatta, Pendidikan Dalam Perspektif Al-Ghazali, (Jambi: Sulthan Thaha Press IAIN STS Jambi,2010)

vi. Zakiah Daradjat, Pendidikan Islam Dalam Keluarga dan Sekolah, (Jakarta: Ruhama, 1995)

vii. Zakiah Daradjat, Ilmu Pendidikan Islam, (Jakarta: Bumi Aksara, 2012)

b. Sumber Sekunder

Sumber sekunder adalah hasil pengumpulan yang dilakukan oleh orang lain dengan maksud tertentu dan mempunyai kategori atau klasifikasi 
menurut keperluan masing-masing dan kegunaan bagi peneliti masingmasing. ${ }^{6}$ Dalam hal ini Sumber data yang berifat sekunder adalah buku rujukan pendukung dalam penelitian, sumber sekunder yang penulis gunakan adalah:

i. Bambang Syamsul Arifin, Psikologi Agama, (Bandung: Pustaka Setia, 2015)

ii. Mansur, Mendidik Anak Sejak Dalam Kandungan, (Yogyakarta: Mitra Pustaka, 2004)

iii. Syamsu Yusuf, Psikologi Perkemabangan Anak \& Remaja, (Bandung: Remaja Rosdakarya, 2012)

2. Teknik Pengumpulan Data

Teknik pengumpulan data adalah cara-cara yang digunakan oleh peneliti untuk mengumpulkan data. ${ }^{7}$ Pengumpulan data dalam penelitian ini adalah dengan cara dokumentasi. Dokumentasi adalah "ditujukan untuk memperoleh data langsung dari tempat penelitian, meliputi bukubuku yang relevan, peraturan-peraturan, laporan kegiatan, foto-foto, fim, dokumenter, data yang relevan penelitian". ${ }^{8}$

3. Teknik Analisa Data

Teknik analisa data adalah cara penghitungan untuk menjawab rumusan masalah dan pengujian hipotesis yang diajukan. ${ }^{9}$ Hipotesis adalah jawaban sementara yang harus di uji kebenarannya. Namun, penelitian yang penulis gunakan dengan kajian pustaka (library research) ini, maka penulis menggunakan tekhnik analisa data kajian isi (countent analysis).

Kajian ini adalah kajian yang menanfaatkan buku atau dokumen untuk menarik kesimpulan, baik kajian isi yang bersifat deduktif maupun kajian isi yang bersifat induktif. ${ }^{10}$ Pada kajian ini peneliti terlebih dahulu

\footnotetext{
${ }^{6}$ S. Nasotion, Metode Research Penelitian Ilmiah, (Jakarta: Bumi Aksara, 2002), Cet. 5, h. 143

7 Riduwan, Skala Pengukuran Variabel-Variabel Penelitian, (Bandung: Alfabeta, 2013), Cet. Ke-10, h. 24

${ }^{8}$ Ibid., h. 31

9 Riduan, Belajar Mudah Penelitian Untuk Guru, Karyawan Dan Peneliti Pemula, (Bandung: Alfabeta, 2015). h. 12

${ }^{10}$ Lexy J. Moleong, Metodologi Penelitian Kualitatif (Bandung:Remaja Rosdakarya, 2013), Cet. 31, h. 220
} 
mengadakan survei data untuk memperoleh informasi dari penelitian terdahulu terhadap pengerjaan tanpa memperdulikan apakah data itu primer atau sekunder, di lapangan atau dilaboratorium. Kemudian, menelusuri leteratur yang ada serta mentelaahnya secara tekun. Setelah itu, peneliti mengungkapkan buah pikiran secara kritis dan analistis. ${ }^{11}$

\section{PEMBAHASAN}

Keluarga (orang tua) menurut para ahli merupakan pendidikan pertama dan pendidikannya adalah orang tua. Orang tua (Bapak dan Ibu) adalah pendidik kodrati. Mereka pendidik bagi anak-anaknya karena secara kodrati, ibu dan bapak diberikan anugerah oleh Tuhan Pencipta berupa naluri orang tua. Karena naluri ini timbul rasa kasih sayang para orang tua kepada anak-anak mereka, hingga secara moral, keduanya merasa punya beban tanggung jawab untuk memelihara, mengawasi, melindungi, dan membimbing keturunan mereka. ${ }^{12}$

Keluarga menurut para pendidik merupakan lapangan pendidikan yang pertama dan pendidikannya adalah kedua orang tua. Sebagai lingkungan yang paling dekat dengan kehidupan anak-anak, keluarga memiliki peran strategis dalam pembinaan karakter anak. ${ }^{13}$

Anak menjadi tanggung jawab orang tua dalam pembentukan karakter dan agamanya. Menurut Ibnu Qoyyim dalam buku karangan Marzuki bahwa tanggung jawab terhadap anak, terutama dalam hal pendidikan, berada dipundak orangtua dan pendidikan (murabbi), apalagi anak tersebut masih berada pada awal pertumbuhannya. Pada awal pertumbuhannya, anak kecil sangat membutuhkan pembimbing yang selalu mengarahkan akhlak dan prilakunya karena anak belum mampu membina dan menata akhlaknya sendiri. Anak sangat membutuhkan pembinaan dan teladan ( $Q u d w a h)$ yang bisa dijadikan panutan baginya. ${ }^{14}$

Mewujudkan anak yang baik dan berkualitas adalah tanggung jawab yang harus dipikul oleh orangtuanya. Anak merupakan amanah yang diberikan oleh Allah kepada orangtuanya yang harus dipertanggungjawabkannya nanti diakhirat.

\footnotetext{
${ }^{11}$ Moh. Nazir, Metode Penelitian, (Bogor Selatan: Ghalia Indonesia, 2005), h. 93

${ }^{12}$ Bambang Syamsul Arifin, Psikologi Agama, (Bandung: Pustaka Setia, 2015), h.55

${ }^{13}$ Marzuki, Pendidikan Karakter Islam, (Jakarta: Amzah, 2015), h.68

${ }^{14}$ Ibid., h. 71
} 
oleh karena itu, orang tua wajib menjaga, membesarkan, merawat, menyantuni, dan mendidik anak-anaknya dengan penuh tanggung jawab dan kasih sayang. Tanggung jawab orang tua terhadap anak-anaknya merupakan tanggung jawab yang berat. Orangtua harus menjaga anak dan seluruh anggota keluarganya agar selamat dari siksa api neraka.

Pendidikan anak dalam Islam menjadi suatu kewajiban yang tidak bisa diabaikan oleh kedua orangtua. Ada beberapa hal yang harus diperhatikan dalam pendidikan agar menjadi generasi Islami. ${ }^{15}$ Berdasarkan petunjuk Al-Qur'an dan Hadis Nabi, Pembina an anak sejak dini bisa dilakukan dengan cara-cara berikut :

1. Mendorong anak untuk membaca Al-Qur'an.

2. Mendorong anak untuk menghafal hadits-hadits Nabi.

3. Mendorong anak untuk mengahayati ciptaan-ciptaan Allah SWT yang tampak disekelilingnya.

4. Mendorong anak sejak berumur tujuh tahun untuk melaksanakan shalat pada waktunya. Dalam rangka ini orang tua (Ayah atau ibu) menjadi panutan bagi anak untuk membiasakan shalat, baik dirumah maupun dimesjid.

5. Melatih anak untuk bersikap sabar dan ridha terhadap apa yang ada dengan menunjukkan hikmah-hikmah yang bisa diperoleh bagi orang yang sabar, baik dalam menghadapi ujian dan cobaan maupun dalam melaksanakan tugas dan kewajiban sehari-hari.

6. Mengajarkan kepada anak tentang arti penting mencintai Allah SWT dan Rasulullah SAW diatas cinta kepada yang lain. Sejak dini orang tua juga harus mengajarkan dan membiasakan kepada anak karakter-karakter utama, seperti sabar, qanaah, syukur, ikhlas, ridha,ikhtiar, dan tawakal kepada Allah.

7. Mengajarkan kepada anak pentingnya penyucian hati dengan menghindari sifat-sifat tercela, seperti syirik, dusta, berani kepada orang tua, iri, dengki, membenci dan berburuk sangka kepada orang lain, serta membicarakan aib orang lain.

8. Melatih anak untuk senang bersedekah kepada fakir miskin, terutama dengan hartanya sendiri, meskipun sekedarnya saja. Ini penting dilakukan untuk mewujudkan sifat dermawan sejak dini pada diri anak.

\footnotetext{
${ }^{15}$ Ibid., h. 72-73
} 
9. Membacakan kisah-kisah para Nabi Allah dan kisah-kisah lain dalam AlQur'an kepada anak agar anak dapat mengambil 'ibrah (pelajaran) dari kisahkisah tersebut.

10. Orangtua harus konsisten dalam menampakkan sikap dan prilaku positif kepada anak sehingga ia mendapatkan model-model berkarakter secara benar.

11. Orang tua Menciptakan suasana keluarga yang penuh dengan kasih sayang dan saling menghormati antaranggota keluarga, baik yang muda terhadap yang dewasa maupun yang dewasaterhadap yang muda, sehingga anak merasa bangga dan tentram terhadap apa yang dilakukan oleh orang-orang dewasa.

12. Menciptakan kondisi yang dapat melatih anak agar kecakapannya tumbuh dan berkembang- baik kecakapan berpikir, emosi, maupun spritual.

13. Mengajak anak untuk terlibat secara langsung dalam berdiskusi dan berdialog dalam suasana demokratis dalam urusan-urusan penting dikeluarga yang memang menjadi bagian dari dunia anak.

14. Menanamkan keimanan yang kuat kepada anak dengan memotivasinya mengahafal ayat-ayat Al-Qur'an (surah-surah pendek) dan hadits-hadits Nabi yang populer. Selain itu, mengajaknya ke mesjid dan berziarah ketempattempat yang bisa menumbuhkan iman, seperti alam terbuka, monumenmonumen Islam, makam, dan lembaga-lembaga pendidikan yang bagus.

15. Membantu anak dalam menerapkan nilai-nilai karakter Islam, terutama dalam interaksi anak sehari-hari bersama teman-temannya, baik dirumah, di sekolah, maupun ditengah-tengah masyarakat. ${ }^{16}$

Anak dilahirkan diatas fitrah, maka orang tualah yang dapat menjadikan mereka menjadi anak yang baik ataupun sebaliknya. Dalam mengembangkan fitrah beragama anak dalam lingkungan keluarga ada beberapa hal lagi yang perlu menjadi kepedulian (perhatian) orangtua yaitu sebagai berikut:

1) Karena orangtua merupakan pembina pribadi yang pertama bagi anak, dan tokoh yang diidentifikasi atau ditiru anak, maka seyogianya dia memiliki kepribadian yang baik atau berakhlakul karimah (akhlak yang mulia). Kepribadian orangtua baik, baik yang menyangkut sikap, kebiasaan berprilaku

${ }^{16}$ Marzuki, Pendidikan Karakter Islam, (Jakarta: Amzah, 2015), h.74 
atau tatacara hidupnya merupakan unsur-unsur pendidikan yang tidak langsung memberikan pengaruh terhadap perkembangan fitrah beragama anak.

2) Orangtua hendaknya memperlakukan anaknya dengan baik. Sikap dan perlakuan orang tua yang baik adalah yang mempunyai karakteristik : (a) memberikan curahan kasih sayang yang ikhlas; (b) bersikap respek / menghargai pribadi anak; (c)menerima anak sebagaimana biasanya, (d) mau mendengar pendapat/keluhan anak; (e)memaafkan kesalahan anak dan meminta maaf bila ternyata orang tua sendiri salah kepada anak, dan (f) meluruskan kesalahan anak dengan pertimbangan atau alasan-alasan yang tepat.

3) Orangtua hendaknya memelihara hubungan yang harmonis antaranggota keluarga (ayah dengan ibu, orangtua dengan anak, dan anak dengan anak). Hubungan yang harmonis, penuh pengertian dan kasih sayang akan membuahkan perkembangan perilaku anak yang baik.

4) Orangtua hendaknya membimbing, mengajarkan atau melatih ajaran agama terhadap anak, seperti: syahadat, shalat (bacaan dan gerakan), berwudhu, do'ado'a, bacaan Al-Qur'an, lafaz zikir dan akhlak terpuji (akhlakul mahmudah) seperti menjalin persaudaraan dengan orang lain, dan menjauhkan diri dari perbuatan yang dilarang Allah. ${ }^{17}$

Ada beberapa tanggung jawab pokok orang tua terhadap anaknya. Hal ini dilakukan secara terperinci dalam buku Prinsip Dasar Akhlak Mulia. Secara garis besar, tanggung jawab orangtua terhadap anaknya adalah:

1) Menerima kehadiran anak sebagai amanah dari Allah

2) mendidik anak dengan cara yang baik

3) Memberikan cinta dan kasih sayang kepada anak

4) Bersikap dermawan kepada anak

5) Tidak membeda-bedakan antara anak laki-laki dan anak perempuan dan hal kasih sayang dan pemberian harta

6) Mewaspadai segala sesuatu yang mungkin memengaruhi pembentukan dan pembinaan anak

7) Tidak menyumpahi anak

${ }^{17}$ Syamsu Yusuf, Psikologi Perkemabangan Anak \& Remaja,( Bandung : Remeja Rosdakarya,2012), h.138-139 
8) Menanamkan akhlak mulia kepada anak. ${ }^{18}$

Secara konseptual, Islam menganjurkan agar orang tua ( ayah dan ibu) dalam kehidupan keluarga bersama anak-anaknya, dapat menjadi teladan atau kesalehan yang akan dikuti anak-anaknya. Kesalehan orang tua akan berdampak pada perkembangan kepribadian anak-anaknya, yang nantinya akan berdampak baik pula terhadap kehidupan anak ditengah masyarakat kerena keluhuran orangtuanya. Orangtua, karenanya sedapat mungkin dapat meningkatkan ketakwaannya kepada Allah SAW sebagai modal dan inspirasi bagi anak-anak dalam mengikuti prilaku dan kesalehan orangtuanya. ${ }^{19}$

Manusia lahir didunia sebagai bayi yang belum dapat menolong dirinya, maka orang tua mempunyai tanggung jawab untuk mendidik anaknya dengan sebaik-baiknya. Sebagai lingkungan pendidikan pertama yang bepengaruh pada perkembangan anak maka tugas orang tua terhadap anak adalah :

1. Mengajarkan ilmu pengetahuan Agama Islam.

2. Menanamkan keimanan dalam Jiwa anak.

3. Mendidik anak agar taat menjalankan Agama.

4. Mendidik anak agar berbudi pekerti yang mulia.

Dari teori-teori tersebut dapat disimpulkan bahwa orang tua sebagai pendidikan pertama bagi anak-anaknya, maka orang tua mempunyai beban tanggung jawab untuk memelihara, mengawasi, melindungi dan membimbing keturunan mereka, terutama dalam beragama. Orang tua yang berkepribadian baik kepada anak akan menjadi model berkarakter secara benar, mendorong, melatih dan mengajarkan anak yang dapat meningkatkan ketakwaannya kepada Allah SWT.

\section{Faktor Yang Mempengaruhi Generasi Islami}

Terkait dengan pendidikan anak, Al-Ghazali mengingkari teori herediritas (naturalisme) yang terlalu mendewa-dewakan factor keturunan. Menurut AlGhazali, anak dilahirkan tanpa dipengaruhi oleh sifat-sifat herediter, kecuali hanya

${ }^{18}$ Ibid. h. 75

${ }^{19}$ Abdullah Idi dan Safarina Hd, Etika Pendidikan (Keluarga, sekolah dan masyarakat), (Jakarta: Raja Grafindo Persada, 2015), h.143 
sedikit. Faktor pendidikan,lingkungan, dan masyarakat, menurut Al-Ghazali, merupakan faktor yang paling kuat dalam mempengaruhi sifat anak. ${ }^{20}$

Al-Ghazali memandang bahwa anak amanah Allah bagi orang tuanya. Hatinya bersih suci bagaikan mutiara yang bersinar dan jauh dari goresan dan gambaran-gambaran. Anak akan menerima apa saja dan cenderung kepada apa saja. Dalam mengomentari pendapat Al-Ghazali,Al-Jumbulati menambahkan, bahwa anak terlahir dalam keadaan fitrah yang netral dan orang tuanyalah yang akan membentuk agamanya. Hal ini dapat dibuktikan bahwa anak berwatak buruk karna balajar dari cara-cara bergaul dan kebiasaan-kebiasaan yang berlaku dilingkungan tempat tinggalnya. Begitu juga halnya tubuh atau fisik anak yang waktu lahir dalam keadaan kurang sempurna kemudian menjadi sempurna dan kuat melalui pertumbuhan, pendidikan, serta makanan. ${ }^{21}$

Anak-anak memerlukan teman bermain. Itu adalah kebutuhan psikologis dan biologis. Dalam bermain dengan teman anak-anak mengembangkan rasa kemasyarakatannya (sosialisasi), berlatih menjadi pemimpin. Dalam bermain anak dapat menemukan jati dirinya. Dengan berteman terbentuk solidaritas, pengetahuan tentang lingkungan bertambah, dan lain-lain. Jadi, berteman berarti melakukan hal yang positif. Jadi, berteman itu perlu. Inilah bagian positif dari kegiatan berteman. Berteman juga memiliki sifat yang negatif. Pengaruh buruk diperoleh juga dari berteman. ${ }^{22}$

Faktor yang sering mengganggu perkembangan anak adalah tidak dimanfaatkannya waktu luang secara tepat. Sejak permulaan perkembangannya, anak-anak gemar bermain. Begitu senangnya anak-anak bersantai sampai-sampai pada saat belajarpun mereka sering bermain dengan temannya. ${ }^{23}$

Tontonan yang sadis dan pornografi (seks) itu merusak mental (selanjutnya fisik), bagi anak-anak pengaruhnya akan besar sekali karana tontonan itu akan meninggalkan kesan yang teguh dan dalam jiwa anak-anak itu. ${ }^{24}$

\footnotetext{
${ }^{20}$ Marzuki, M.Ag. Pendidikan Karakter Islam, (Jakarta: Amzah, 2015), h.75

${ }^{21}$ Ibid. h. 75

${ }^{22}$ Ahmad Tafsir, Ilmu Pendidikan Islami, (Bandug : PT Remaja Rosdakarya, 2012), h.

${ }^{23}$ Ibid, h. 267

${ }^{24}$ Ibid, h. 268
} 265 
Cekcok ayah ibu tidak sekedar membuat gelisah anak-anak, cekcok itu juga menimbulkan dampak psikologis yang buruk pada anak-anak. Mereka merasa kurang aman karna pelindungnya ternyata tidak akur. ${ }^{25}$ Terkadang cekcok berakhir dengan perceraian, perceraian ternyata memberikan dampak yang kurang baik terhadap perkembangan keperibadian anak. ${ }^{26}$

Mengirim anak ke sekolah hal yang tidak dapat dihindari,banyak orang tua yang merasa tugas anaknya sudah selesai bila ia sudah menyekolahkan anak nya. Ini suatu keliruan yang serius. Pertama, karna sekolah sebenarnya hanya membina anak pada aspek jasmani (psikomotor, keterampilan) da akal (kecerdasan, pengetahuan). Aspek kejiawaan, tegasnya aspek afektif anak, tidak begitu diperhatikan disekolah.

\section{KESIMPULAN}

Peran Orang Tua dalam Mendidik Generasi Islami yang terpenting adalah: 1) mendorong anak sejak berumur tujuh tahun untuk melaksanakan shalat pada waktunya untuk membiasakan shalat, baik dirumah maupun dimesjid, 2) melatih anak untuk bersikap sabar dan ridha terhadap apa yang ada dengan menunjukkan hikmah-hikmah yang bisa diperoleh bagi orang yang sabar, baik dalam menghadapi ujian dan cobaan maupun dalam melaksanakan tugas dan kewajiban sehari-hari, 3) mengajarkan kepada anak tentang arti penting mencintai Allah swt dan Rasul-Nya diatas cinta kepada yang lain. 4) mengajarkan dan membiasakan kepada anak karakter-karakter utama, seperti sabar, qanaah, syukur, ikhlas, ridha,ikhtiar, dan tawakal kepada Allah. 5) penyucian hati dengan menghindari sifat-sifat tercela, seperti syirik, dusta, berani kepada orang tua, iri, dengki, membenci dan berburuk sangka kepada orang lain, serta membicarakan aib orang lain, 6) melatih anak untuk senang bersedekah kepada fakir miskin, terutama dengan hartanya sendiri, meskipun sekedarnya saja, 7) membacakan kisah-kisah para Nabi Allah dan kisah-kisah lain dalam Al-Qur'an kepada anak agar anak dapat mengambil 'ibrah (pelajaran) dari kisah-kisah tersebut. 8) konsisten dalam menampakkan sikap dan prilaku positif kepada anak sehingga ia mendapatkan

\footnotetext{
${ }^{25}$ Ibid, h. 269

${ }^{26}$ Syamsu Yusuf, Psikologi Perkemabangan Anak \& Remaja,( Bandung : Remeja Rosdakarya,2012), h.44
} 
model-model berkarakter secara benar. 9) memelihara hubungan yang harmonis antaranggota keluarga (ayah dengan ibu, orangtua dengan anak, dan anak dengan anak). Hubungan yang harmonis, penuh pengertian dan kasih sayang akan membuahkan perkembangan perilaku anak yang baik. ${ }^{27} 10$ ) menciptakan kondisi yang dapat melatih anak agar kecakapannya tumbuh dan berkembang- baik kecakapan berpikir, emosi, maupun spritual. 11) mengajak anak untuk terlibat secara langsung dalam berdiskusi dan berdialog dalam suasana demokratis dalam urusan-urusan penting dikeluarga, 12) menanamkan keimanan yang kuat kepada anak dengan memotivasinya mengahafal ayat-ayat Al-Qur'an (surah-surah pendek) dan hadis-hadis Nabi yang populer, 13) mengajaknya ke mesjid dan berziarah ketempat-tempat yang bisa menumbuhkan iman, seperti alam terbuka, monumen-monumen Islam, makam, dan lembaga-lembaga pendidikan yang bagus, 14) Orang tua membantu anak dalam menerapkan nilai-nilai karakter Islam, terutama dalam interaksi anak sehari-hari bersama teman-temannya, baik dirumah, di sekolah, maupun ditengah-tengah masyarakat. ${ }^{28}$ 15) memperhatikan dan mengawasi : teman bermain, Tontonan Televisi, Lingkungan Sekolah dan lain sebagainya.

\section{DAFTAR PUSTAKA}

Abdullah Idi dan Safarina Hd, Etika Pendidikan (Keluarga, sekolah dan masyarakat), (Jakarta: Raja Grafindo Persada, 2015)

Abdul Mujib, Jusuf Mudzakir, Ilmu Pendidikan Islam, (Jakarta: Kencana Prenada Media Group, 2008)

Ahmad Tafsir, Ilmu Pendidikan Islami, (Bandug: PT Remaja Rosdakarya, 2012)

Bambang Syamsul Arifin, Psikologi Agama, (Bandung: Pustaka Setia, 2015)

Lexy J. Moleong, Metodologi Penelitian Kualitatif (Bandung:Remaja Rosdakarya, 2013), Cet. 31

Marzuki, Pendidikan Karakter Islam, (Jakarta: Amzah, 2015)

\footnotetext{
${ }^{27}$ Syamsu Yusuf, Psikologi Perkemabangan Anak \& Remaja,( Bandung : Remaja Rosdakarya,2012), h.139

${ }_{28}$ Marzuki, Pendidikan Karakter Islam, (Jakarta: Amzah, 2015), h.74
} 
Mansur, Mendidik Anak Sejak Dalam Kandungan, (Yogyakarta: Mitra Pustaka, 2004)

Muhammad Hatta, Pendidikan Dalam Perspektif Al-Ghazali, (Jambi: Sulthan Thaha Press IAIN STS Jambi, 2010)

Moh. Nazir, Metode Penelitian, (Bogor Selatan: Ghalia Indonesia, 2005)

Riduwan, Skala Pengukuran Variabel-Variabel Penelitian, (Bandung: Alfabeta, 2013), Cet. Ke-10

Riduan, Belajar Mudah Penelitian Untuk Guru, Karyawan Dan Peneliti Pemula, (Bandung: Alfabeta, 2015)

Syamsu Yusuf, Psikologi Perkemabangan Anak \& Remaja,(Bandung : Remaja Rosdakarya, 2012)

S. Nasotion, Metode Research Penelitian Ilmiah, (Jakarta: Bumi Aksara, 2002), Cet. 5

Zakiah Daradjat, Pendidikan Islam Dalam Keluarga dan Sekolah, (Jakarta: Ruhama, 1995)

Zakiah Daradjat, Ilmu Pendidikan Islam, (Jakarta: Bumi Aksara, 2012) 